\title{
Micropropagation of Rubus chrysophyllus Reinw. ex Miq. and Rubus fraxinifolius Poir.
}

\author{
Lily Ismaini*, Destri, Muhammad Imam Surya
}

Cibodas Botanical Garden, Indonesian Institute of Sciences, Cianjur, Indonesia

\section{ABSTRACT}

Rubus chrysophyllus and Rubus fraxinifolius are a native species in Indonesia, which has highly potential to be developed as fruits crops. Propagation is an important factor in developing a fruit cultivation. In vitro micropropagation is an important instrument to improve the quality of seedling. Our experiment was aimed to study the micropropagation of $R$. chrysophyllus and $R$. fraxinifolius. The shoot tips were cultured on MS medium supplemented with $10 \mathrm{mg} / \mathrm{L}$ indole-3-butyric acid (IBA) for enhancing roots of $R$. chrysophyllus and $R$. fraxinifolius in the in vitro condition. Then, the rooted plantlets were transplanted into cocopeat media for acclimatization. The results showed that $R$. chrysophyllus and $R$. fraxinifolius gave a different response on the medium contain 10 $\mathrm{mg} / \mathrm{L}$ of IBA. The $R$. fraxinifolius shows the best results compared to $R$. chrysophyllus on 14 days after subculture. The roots length and roots numbers of $R$. fraxinifolius and $R$. chrysophyllus were $9.13 \mathrm{~cm}$ and $11.25 ; 2.20 \mathrm{~cm}$ and 2.00, respectively. Although $R$. fraxinifolius was growing better than $R$. chrysophyllus, but after acclimatization $R$. chrysophyllus were able to grow faster than $R$. fraxinifolius. Moreover, on the parameters of plant height shows that $R$. chrysophyllus $(9.20 \mathrm{~cm})$ were growth higher than $R$. fraxinifolius $(4.05 \mathrm{~cm})$ during acclimatization.

Keywords: Rubus chrysophyllus, Rubus fraxinifolius, micropropagation, indole-3-butyric acid (IBA)

\section{INTRODUCTION}

Rubus chrysophyllus and Rubus fraxinifolius (Figure 1) are collections of Cibodas Botanical Garden (CBG). R. chrysophyllus was collected from Mount Singgalang - West Sumatera on $2525 \mathrm{~m}$ above sea level. Van Steenis [1] reported that $R$. chrysophyllus has a sweet taste comparing with others species. Moreover, $R$. fraxinifolius is a garden origin collection in CBG. $R$. chrysophyllus is distributed in Sumatra, Java and Lombok [2], but has not cultivated yet. In Indonesia, $R$. fraxinifolius is distributed in Borneo, Java, Lesser Sunda Islands, Celebes and Moluccas [2]. Moreover, $R$. fraxinifolius also called as 'Arben', recently it was cultivated in CBG-West Java.

In vitro propagation is an important technique for production of Rubus seedling. It is due to this technique guarantees quality and safety compared to traditional production. However, successful in vitro propagation have been reported for many members of the genus Rubus involving callus culture, shoot tips growth, roots development, and proliferation [3-7], but

\section{${ }^{*}$ Corresponding author:}

Lily Ismaini

Cibodas Botanical Garden, Indonesian Institute of Sciences

Jalan Kebun Raya Cibodas, Po. Box. 19 SDL Cipanas, Cianjur, Indonesia 43253

E-mail: lily.ismaini@lipi.go.id the study of in vitro propagation of Rubus spp. from Indonesian Mountain's Forests was very limited. Currently, all of Rubus spp. in Indonesia is propagated by seed and cutting techniques. $R$. chrysophyllus and $R$. fraxinifolius are the potential species for breeding material in order to domesticate and develop a new cultivar of wild raspberry.

The in vitro propagation of $R$. chrysophyllus and $R$. fraxinifolius have not been clearly studied. The aim of this experiments was to examine the micropropagation methods of $R$. chrysophyllus and $R$. fraxinifolius.

\section{MATERIALS AND METHODS \\ Plant material}

The experiment was conducted in the Laboratory of Cibodas Botanical Gardens. The seeds of $R$. chrysophyllus and $R$. fraxinifolius which were used for the experiments was collected from Cibodas Botanical Gardens.

\section{How to cite:}

Ismaini L, Destri, Surya MI (2017) Micropropagation of Rubus chrysophyllus Reinw. ex Miq. and Rubus fraxinifolius Poir. J. Trop. Life. Science 7 (1): 30-76. 


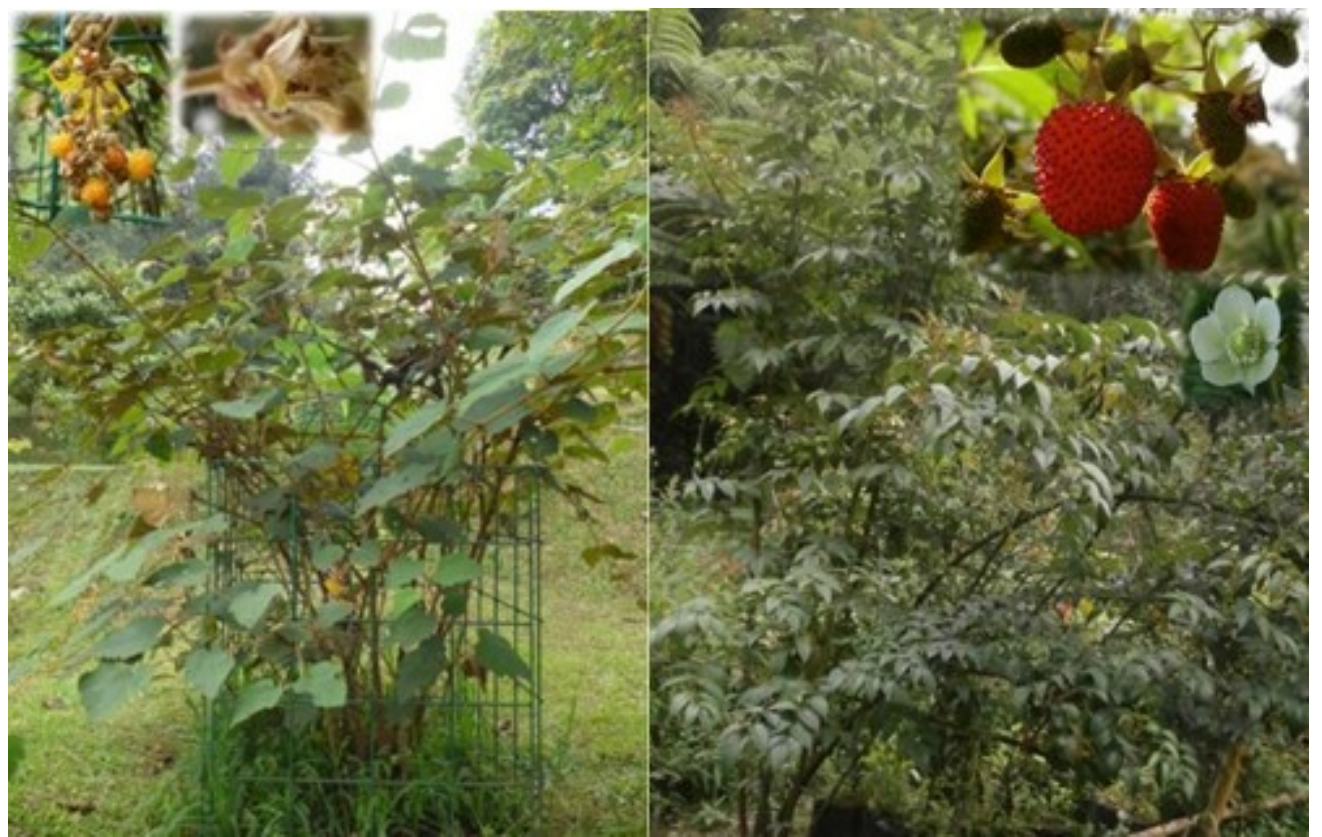

(a)

(b)

Figure 1. The plants and fruits of R. chrysophyllus (a) and R. fraxinifolius (b)

\section{Seed germination}

Rubus's seeds from mature fruits were first washed under running tap water, continued with a detergent solution for $5 \mathrm{~min}$ to remove pulp, then soaked for 15 min in tween 80. In order to minimize fungal and bacteria contamination, seeds were treated with a solution of fungicide (Benlox) and bactericide (Agrept) for $20 \mathrm{~min}$ by gentle shaking. Final steps of seeds surface sterilization were transferred to $70 \%$ ethanol for $1 \mathrm{~min}$ and followed by $\mathrm{NaOCl}$ solution (Sunklin ${ }^{\circledR}$ 20\%) for $15 \mathrm{~min}$. Each treatment was followed by repeated washing for a minimum of 3 times in sterile distilled water. The seeds were cultured in a bottle containing $20 \mathrm{~mL}$ of MS medium [8]. The medium was also enriched with $30 \mathrm{~g} / \mathrm{L}$ sucrose and solidified with 8 $\mathrm{g} / \mathrm{L}$ agar. The $\mathrm{pH}$ was adjusted to 5.8 before autoclaving at $121^{\circ} \mathrm{C}$ and $1 \mathrm{~atm}$ for $20 \mathrm{~min}$.

For induction of rooting, shoot tips explants of $R$. chrysophyllus and $R$. fraxinifolius seedling were cultured on MS basal medium supplemented with growth regulator indole-3-butyric acid (IBA) $10 \mathrm{mg} / \mathrm{L}, 30 \mathrm{~g} / \mathrm{L}$ sucrose and solidified with $8 \mathrm{~g} / \mathrm{L}$ agar. The observations were made on root length, a number of leaves, buds, and roots.

\section{Acclimatization of plants}

Well-rooted shoots were removed from the culture medium, and the roots were washed gently with water to remove agar. The plantlets were then dipped into fungicide (Benlox) for few seconds to disinfect the plants. Plantlets were transferred to small plastic pots (8 $\mathrm{cm}$ in diameter) containing a cocopeat media. The plantlets were kept in a sealed chamber to maintain the humidity, after 1 month the plantlets were placed in the greenhouse for acclimatization. The plantlets were observed between 0 to 21 weeks after acclimatization (WAA). The observations were made on plant height, some buds, and the number of leaves.

\section{RESULTS AND DISCUSSION}

Micropropagation of $R$. chrysophyllus and $R$. fraxinifolius were studied using a shoot explants. In general, the results show that $R$. fraxinifolius gave a better response on MS medium containing $10 \mathrm{mg} / \mathrm{L}$ IBA than $R$. chrysophyllus (Figure 2). The response of $R$. chrysophyllus and $R$. fraxinifolius occurred on 14 days after transfer. On the parameters of roots length and roots numbers, $R$. fraxinifolius shows the best results, with average values, were $9.13 \mathrm{~cm}$ and 11.25 , while $R$. chrysophyllus shows the average values were $2.20 \mathrm{~cm}$ and 2.00. Najaf-Abadi and Hamidoghli [9] reported that the additional of IBA had a significant effect on the number of roots produced and root length. Meng et al. [10] reported that auxins from IBA modified by cytokinin were the best plant growth regulator for promoting somatic embryogenesis. Furthermore, in 


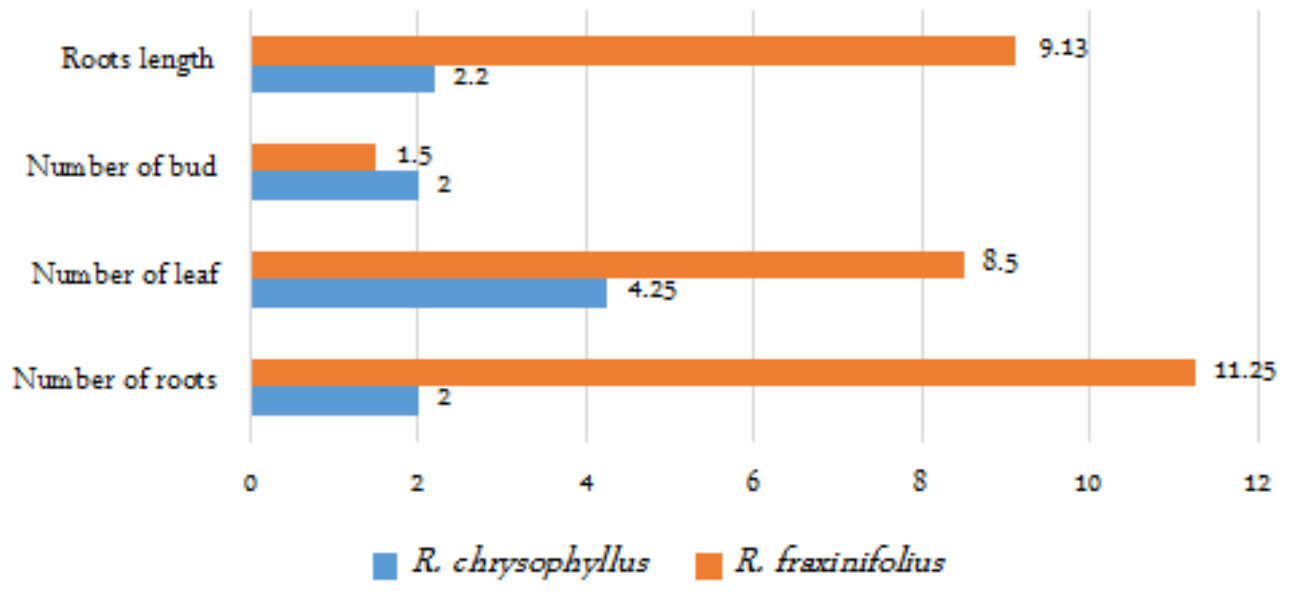

Figure 2. The effect of IBA medium on $R$. chrysophyllus and $R$. fraxinifolius growth by in vitro culture

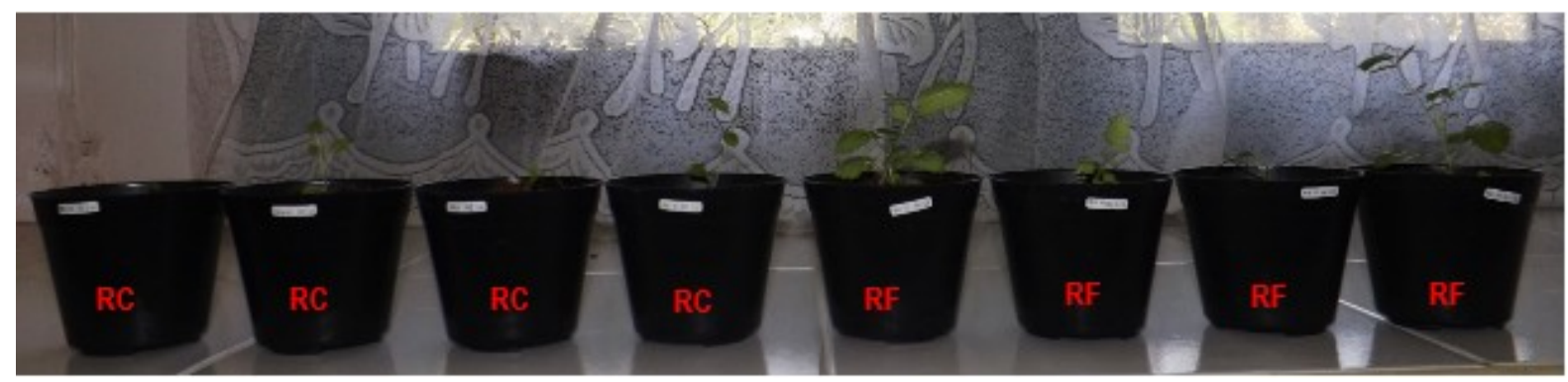

Figure 3. R. chrysophyllus (RC) and $R$. fraxinifolius (RF) growths on 50 days after acclimatization

our experiment, the result show that either $R$. chrysophyllus or $R$. fraxinifolius were produced less number of buds (Figure 2). Martinussen et al. [5] reported that auxins promoted root formation in vitro but inhibit shoot or bud formations.

On the parameter of leaf number, the results show that leaf number of $R$. chrysophyllus (4.25) was lower than $R$. fraxinifolius (8.50). Reed [3] reported that each species of Rubus has different responses to the in vitro medium. It was in line with our experiment which is $R$. fraxinifolius and $R$. crysophyllus gave different responses into the same in vitro medium (Figure 2). Moreover, the application of growth regulator application is varied, depending on the genotype and physiological condition of the plant tissue.

Acclimatization from in vitro to ex Vitro condition is a critical step on Rubus micropropagation. Cocopeat was used as media for acclimatization $R$. chrysophyllus and $R$. fraxinifolius (Figure 3 ). Three parameters were observed during 21 weeks after acclimatization. The results show that either $R$. chrysophyllus or $R$. fraxinifolius gave good responses. Although during in vitro culture $R$. fraxinifolius were able to produce more roots than $R$. chrysophyllus, but after acclimatization, $R$. chrysophyllus could grow faster than $R$. fraxinifolius. It can be seen in figure 4 that the average of plant height of $R$. chrysophyllus was above $8 \mathrm{~cm}$ at 21 weeks after acclimatization, and $R$. fraxinifolius were only $4 \mathrm{~cm}$. Martinussen et al. [5] reported that two cultivars of cloudberry (Rubus chamaemorus), the female 'Fjellgull' and the male 'Apollen', gave different response during in vitro propagation and after acclimatization. In the other hand, the opposite results occurred on parameter number of leaves. The results show that the number of leaves which produced by $R$. fraxinifolius (11.20) were higher than $R$. chrysophyllus (6.00) (Figure 4).

Micropropagation has been extensively used for the rapid multiplication of many plant species. However, acclimatization of in vitro grown plants is very difficult needing an understanding of the growth habit and factors including the root apparatus of the plants to be acclimatized, surrounding temperature, humidity, and soil template responsible for plant growth under in vitro and ex Vitro conditions. As the in vitro cultivated plants are very sensitive to each of these even a very small lag in the look after of the cultured tissue plants can lead to damage and death [11]. The specific in vitro environment, with artificial medium usually sup- 


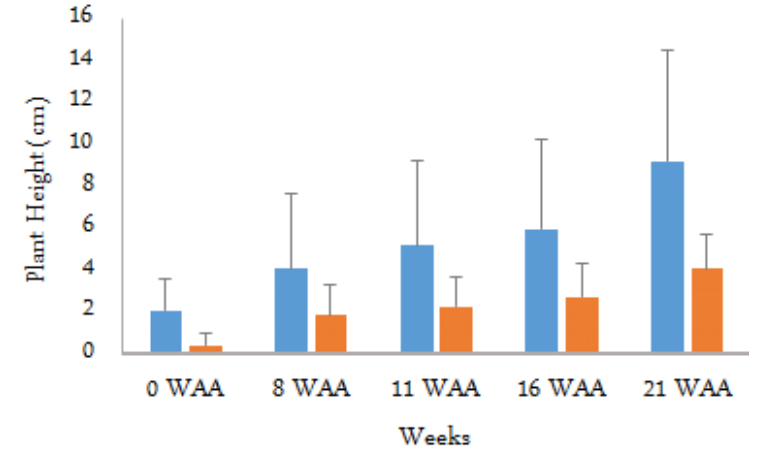

(a)

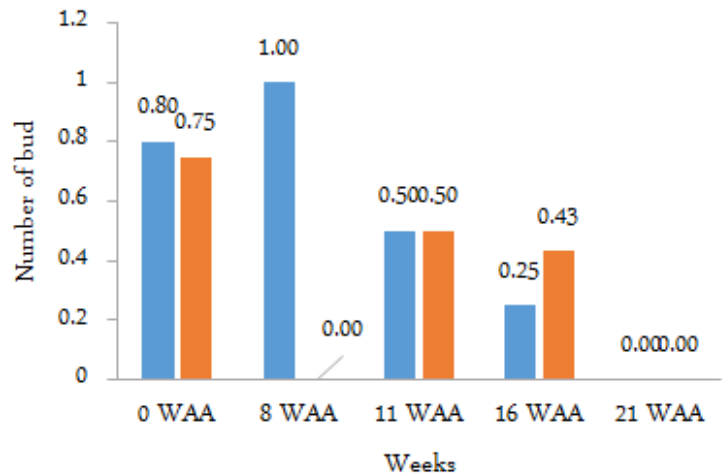

(b)

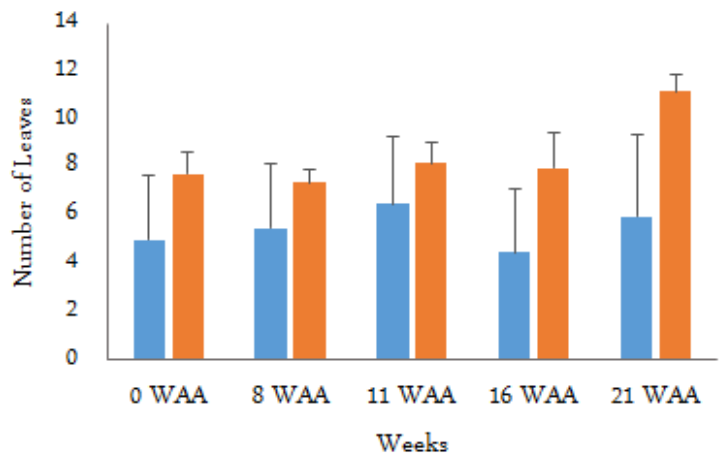

(c)

R. chrysophyllus $R$. fraxinifolius

Figure 4. Height (a), number of bud (b) and number of leaves (c) of $R$. chrysophyllus and $R$. fraxinifolius from 0 to 21 weeks after acclimatization (WAA).

plied with sugar(s), the growth of plantlets in small airtight vessels with high air humidity, low gas exchange and thus a $\mathrm{CO} 2$-shortage during almost the whole photoperiod, ethylene production and relatively low photosynthetic photon flux density, induces disturbances in plant development and photosynthetic performance $[12,13,14]$. Furthermore, the in vitro propagation is an intensive labor, and the acclimatization step is needed additional treatment to produced plantlet before it is commercialized and transported to the growers.

\section{CONCLUSION}

Rubus chrysophyllus and $R$. fraxinifolius gave a different response on the medium contain $10 \mathrm{mg} / \mathrm{L}$ of IBA. $R$. fraxinifolius was more responsive during in vitro culture compared to $R$. chrysophyllus. Although $R$. fraxinifolius was growing better than $R$. chrysophyllus, but after acclimatization $R$. chrysophyllus were able to grow faster than $R$. fraxinifolius. It was indicated by the value of plant height of $R$. chrysophyllus was higher than $R$. fraxinifolius. A further experiment is necessary to determine the excellent medium for $R$. chrysophyllus.

\section{ACKNOWLEDGMENT}

The authors would like to express acknowledgment to Indonesian Institute of Sciences for financial support on wild Rubus domestication program at Cibodas Botanical Garden through the program of DIPA Tematik.

\section{REFERENCES}

1. van Steenis CGGJ (1972) The Mountain Flora of Java. E. J. Brill, Leiden.

2. Kalkman C (1993) Rosaceae. Leiden University. Flora Malesiana ser. I. Vol. 11 (2): 227-351.

3. Reed BM (1990) Multiplication of Rubus germplasm in vitro: A screen of 256 accessions. Fruit Varieties Journal 44 (3): 141-148.

4. Palonen P, Buszard D (1998) In vitro screening for cold hardiness of raspberry cultivars. Plant Cell, Tissue and Organ Culture 53 (3): 213-216.

5. Martinussen I, Nilsen G, Svenson L et al. (2004) In vitro propagation of cloudberry (Rubus chamaemorus). Plant Cell, Tissue and Organ Culture 78 (1): 43-49.

6. Fira A, Clapa D, Plopa C. (2009) Micropropagation of blackberry thornless cultivars. Scientific Papers of the R.I.F.G. Pitesti 25: 213-221.

7. Dziedzic E, Jagła J (2013) Micropropagation of Rubus and Ribes spp. In: Lambardi M, Ozudogru EA, Jain SM (eds) Protocols for micropropagation of selected economicallyimportant horticultural plants. Humana Press, Totowa, NJ, pp 149-160.

8. Murashige T, Skoog F (1962) A revised medium for rapid growth and bioassay with tobacco tissue. Physiologia Plantarum 15: 473-497.

9. Najaf-Abadi AJ, Hamidoghli Y (2009) Micropropagation of thornless trailing blackberry (Rubus sp.) by axillary bud explants. Australian Journal of Crop Science 3 (4): 191194.

10. Meng R, Chen THH, Finn CE, Li Y (2004) Improving in vitro plant regeneration from leaf and petiole explants of 
'Marion' Blackberry. Horticultural Science 39 (2): 316320.

11. Mokhtarzadeh S, Hajyzadeh M, Ahmad HA, Khawar KM (2013) The problems in acclimatization of in vitro multiplied plants of Lavandula angustifolia Miller under field conditions. ISHS Acta Horticulturae 988 71-76. doi: 10.17660/ActaHortic.2013.988.6.

12. Kozai T (1991) Micropropagation under photoautotrophic conditions. In: Micropropagation. Springer Netherlands,
Dordrecht, pp 447-469.

13. Pospisilova J, Catsky J, Sestak Z (1997) Photosynthesis in plants cultivated in vitro. In: Pessarakli, M. (ed.): Handbook of Photosynthesis. CRC Press, New York, pP 525540 .

14. Kadleček P, Tichá I, Haisel D et al. (2001) Importance of in vitro pretreatment for ex vitro acclimatization and growth. Plant Science 161 (4): 695-701. 